\title{
Change detection in a time series of polarimetric SAR data by an omnibus test statistic
} and its factorization

\author{
Nielsen, Allan Aasbjerg; Conradsen, Knut; Skriver, Henning
}

Published in:

Proceedings of SPIE: Image and Signal Processing for Remote Sensing XXII

Link to article, DOI:

$10.1117 / 12.2242178$

Publication date:

2016

Document Version

Publisher's PDF, also known as Version of record

Link back to DTU Orbit

Citation (APA):

Nielsen, A. A., Conradsen, K., \& Skriver, H. (2016). Change detection in a time series of polarimetric SAR data by an omnibus test statistic and its factorization. In Proceedings of SPIE: Image and Signal Processing for

Remote Sensing XXII (Vol. 10004). SPIE - International Society for Optical Engineering. Proceedings of SPIE The International Society for Optical Engineering https://doi.org/10.1117/12.2242178

\section{General rights}

Copyright and moral rights for the publications made accessible in the public portal are retained by the authors and/or other copyright owners and it is a condition of accessing publications that users recognise and abide by the legal requirements associated with these rights.

- Users may download and print one copy of any publication from the public portal for the purpose of private study or research.

- You may not further distribute the material or use it for any profit-making activity or commercial gain

- You may freely distribute the URL identifying the publication in the public portal 


\title{
Change detection in a time series of polarimetric SAR data by an omnibus test statistic and its factorization (Conference Presentation)
}

\author{
Allan A. Nielsen, Knut Conradsen, Henning Skriver, Technical Univ. of Denmark (Denmark)
}

\begin{abstract}
Test statistics for comparison of real (as opposed to complex) variance-covariance matrices exist in the statistics literature [1].

In earlier publications we have described a test statistic for the equality of two variance-covariance matrices following the complex Wishart distribution with an associated p-value [2]. We showed their application to bitemporal change detection and to edge detection [3] in multilook, polarimetric synthetic aperture radar (SAR) data in the covariance matrix representation [4]. The test statistic and the associated p-value is described in [5] also. In [6] we focussed on the block-diagonal case, we elaborated on some computer implementation issues, and we gave examples on the application to change detection in both full and dual polarization bitemporal, bifrequency, multilook SAR data.
\end{abstract}

In [7] we described an omnibus test statistic $\mathrm{Q}$ for the equality of $\mathrm{k}$ variance-covariance matrices following the complex Wishart distribution. We also described a factorization of $Q=R 2 R 3 \ldots R k$ where $Q$ and $R j$ determine if and when a difference occurs. Additionally, we gave p-values for $\mathrm{Q}$ and Rj. Finally, we demonstrated the use of $\mathrm{Q}$ and $\mathrm{Rj}$ and the $\mathrm{p}$-values to change detection in truly multitemporal, full polarization SAR data.

Here we illustrate the methods by means of airborne L-band SAR data (EMISAR) [8,9]. The methods may be applied to other polarimetric SAR data also such as data from Sentinel-1, COSMO-SkyMed, TerraSAR-X, ALOS, and RadarSat-2 and also to single-pol data.

The account given here closely follows that given our recent IEEE TGRS paper [7].

Selected References

[1] Anderson, T. W., An Introduction to Multivariate Statistical Analysis, John Wiley, New York, third ed. (2003).

[2] Conradsen, K., Nielsen, A. A., Schou, J., and Skriver, H., "A test statistic in the complex Wishart distribution and its application to change detection in polarimetric SAR data," IEEE Transactions on Geoscience and Remote Sensing 41(1): 4-19, 2003.

[3] Schou, J., Skriver, H., Nielsen, A. A., and Conradsen, K., "CFAR edge detector for polarimetric SAR images," IEEE Transactions on Geoscience and Remote Sensing 41(1): 20-32, 2003.

[4] van Zyl, J. J. and Ulaby, F. T., "Scattering matrix representation for simple targets," in Radar Polarimetry for Geoscience Applications, Ulaby, F. T. and Elachi, C., eds., Artech, Norwood, MA (1990).

[5] Canty, M. J., Image Analysis, Classification and Change Detection in Remote Sensing,with Algorithms for ENVI/IDL and Python, Taylor \& Francis, CRC Press, third revised ed. (2014).

[6] Nielsen, A. A., Conradsen, K., and Skriver, H., "Change detection in full and dual polarization, single- and multifrequency SAR data," IEEE Journal of Selected Topics in Applied Earth Observations and Remote Sensing 8(8): 4041-4048, 2015.

[7] Conradsen, K., Nielsen, A. A., and Skriver, H., "Determining the points of change in time series of polarimetric SAR data," IEEE Transactions on Geoscience and Remote Sensing 54(5), 3007-3024, 2016.

[9] Christensen, E. L., Skou, N., Dall, J., Woelders, K., rgensen, J. H. J., Granholm, J., and Madsen, S. N., "EMISAR: An absolutely calibrated polarimetric L- and C-band SAR," IEEE Transactions on Geoscience and Remote Sensing 36: 1852-1865 (1998).

View presentation recording on the SPIE Digital Library: http://dx.doi.org/10.1117/12.2242178.5229527637001

Image and Signal Processing for Remote Sensing XXII, edited by Lorenzo Bruzzone,

Francesca Bovolo, Proc. of SPIE Vol. 10004, 1000411 - () 2016 SPIE

CCC code: $0277-786 \mathrm{X} / 16 / \$ 18 \cdot$ doi: $10.1117 / 12.2242178$ 